OPEN ACCESS

Edited by:

Tiago Correia,

University Institute of Lisbon, Portugal

Reviewed by:

Joana Almeida,

University of London,

United Kingdom

Tuba Agartan,

Providence College, United States

${ }^{*}$ Correspondence:

Ivy Lynn Bourgeault

ivy.bourgeaul@@uottawa.ca

Specialty section: This article was submitted to

Medical Sociology,

a section of the journal

Frontiers in Sociology

Received: 13 April 2017 Accepted: 09 October 2017 Published: 29 November 2017

Citation:

Bourgeault IL (2017) Conceptualizing the Social and Political Context of the Health Workforce: Health Professions, the State, and Its Gender Dimensions.

Front. Sociol. 2:16. doi: $10.3389 /$ fsoc.2017.00016

\section{Conceptualizing the Social and Political Context of the Health Workforce: Health Professions, the State, and Its Gender Dimensions}

\author{
Ivy Lynn Bourgeault* \\ Telfer School of Management, University of Ottawa, Ottawa, ON, Canada
}

This paper attempts to address the theoretical vacuum that exists within the growing literature on the sufficiency and stability of the health workforce that has dominated health policy agendas worldwide. Conceptualizing the context of the health workforce, and the relationship between health professions and the state more specifically, draws upon critical areas of social theory and health. The sociology of professions literature, and its focus on professional projects, point to the important role that the state plays as an audience for social closure strategies, those that seek resources to the exclusion of others. Depicting the state in this manner, however, does not enable us to explain why some state-directed strategies are successful whereas others are not. An expanded analysis of the state, its interests and the efficacy of the strategies directed toward it is augmented with reference to health policy literature. I present a model which attempts to integrate the conceptualization of the state in the health professions and policy literatures as a means to better understand the context of the relations between the state and the health professions. The specific gender dimensions of this relationship are then explored through a consideration of female health professional projects and the role of women vis-à-vis the state.

Keywords: health professions, professional projects, the state, gender dimensions, theory

\section{INTRODUCTION}

Although concerns about the sufficiency and stability of the health workforce have dominated health policy agendas worldwide (World Health Organization, 2006), much of this has occurred within a theoretical vacuum. Conceptualizing the context of the health workforce, and the relationship between health professions and the state in particular, draws upon critical and sometimes neglected areas of the sociology of health. Indeed, a key problem in the sociology of health professions literatures is the need for a better understanding of the interface between professions and the state (MacDonald, 1995). This is particularly true of the literature on professionalization or professional projects (Larson, 1977, Witz, 1992), especially those that occur within the health care division of labor (e.g., Larkin, 1983, Willis, 1989, Coburn et al., 1999). With a few exceptions, many of these accounts have focused almost exclusively on the liberal democratic form of the state plays as an audience for social closure strategies. These accounts have focused almost exclusively on the liberal democratic form of the state. The state has also been found in some cases to be particularly responsive 
to some female professional projects, and this support can have some intriguing gender dimensions to it (Witz, 1992, Sandall et al., 2001, Benoit et al., 2005, Bourgeault, 2006).

Conceptualizing the role of the state as only an audience, however, does not enable us to explain why some strategies directed toward the state are successful and others are not, nor is it particularly helpful in explaining how gender intersects the relationship between the state and certain health professions. To begin to address these limitations and afford a more thorough analysis of the role of the (liberal democratic) state, its interests and the factors affecting the efficacy of the strategies directed toward it, the policy literature and the literature on women and the state is instructive. State and policy scholars detail the structure and organization of networks of interest groups within and between policy communities, outline the policy-making process, and delineate the interests of various state forms (e.g., Lavis et al., 2012). It treats the state less as a "black box", as is the case of some of the professions literature, which is helpful in elucidating state-professional relations. More fully unpacking or bringing the state back into sharper focus is consistent with what some authors have undertaken (Schmidt, 2009), and with what others have called the move toward a new institutionalism in the sociology of the professions (Le Bianic, 2003; Leicht et al., 2009). Some of the policy literature fails to fully conceptualize the differential in power, status, and influence of various (occupational) interest groups. This is particularly important to acknowledge in some of the more highly stratified divisions of labor, which is the case of health care. The literature on women and the state helps to explain the gendered nature of these differentials, augmenting our understanding of these power differentials even further.

Thus, a conceptual integration of these bodies of literature-most of which have tended to exist in separate "silos"-seems warranted to better capture the context and process of state and profession interactions. In this paper, I outline a heuristic conceptual model which offers and approach to this integration. This is constructed first through a detailed description of the conceptualizations of the state and health professions in the sociology of professions literatures followed by the unpacking of the state in the policy literature and the feminist literature on women, the state and professions. Throughout the paper are brief illustrations from my published empirical research on female professional projects in Canada that attempt to establish new or expand existing health professional roles which provided the impetus for this conceptual integration.

\section{CONCEPTUALIZATIONS OF THE STATE IN THE PROFESSIONS LITERATURE}

\section{The State As Audience}

As noted at the outset, the state has been recognized as playing a key role in the professionalization process of many professions from the dominant to subordinate (Larkin, 1983, 2005). Indeed, the state is often recognized as being the primary focus of legalistic closure strategies to attain professional status. Professions aim to enhance their privilege and secure a monopoly of the provision of services of a particular kind and such monopolies and privileges can only be granted by the state. The medical professions in Britain, Canada, and the US have and continue to use administrative structures within the state to secure and further their collective interests (Larson, 1977; Coburn, 1993).

Similarly, Witz (1992), in discussing the professional projects of midwives and nurses in Britain at the turn of the twentieth century, details how representatives of these projects employed gendered, legalistic social closure tactics of seeking state sponsored systems of registration. She describes how the Midwives' Institute, for example, wanted to secure state legislation regulating midwifery but given that women did not yet have the vote it was necessary for the Institute to mobilize proxy male power to represent their interests to key state decision-makers. To this end, the Institute enlisted the aid of women of position and through them gained the support of their (male) relatives and friends in Parliament. Their strategies were successful in the passage of the Midwifery Act in 1902. Witz (1992) argues that, "female professional projects, albeit mediated by proxy male power, did have considerable effectiveness at the level of the state" (p. 208).

These depictions of the state in the professionalization literature is primarily as an audience of the aspiring professions legalistic closure strategies-something external to the professions to whom support was sought to advance their agenda. Depicted in this way, this view is consistent with Abbott's (1988) conceptualization of the state in System of Professions. Specifically, he describes that the state-in addition to the workplace and the public-as an audience or site for conflicts over professional jurisdiction. Further, Abbott argues that professions interact with the state through the legislative process of negotiating legal conditions of governance over professional practice. Similarly, Freidson (2001) compares states in terms of how conducive an environment it creates for professionalism-liberal states are much more favorable than highly centralized states. But the state is not merely an audience for "pluralist" (Le Bianic, 2003) professionalization efforts, particularly in an evolving neo-liberal economic context. Although being an audience does not necessarily mean that the state, and actors within the state, lack agency; its agency, however, remains relatively under conceptualized.

\section{The State As Actor}

The state has been recognized as having more agency in other streams of the professions literature-that is, as an actor (or set of actors) with its own interests and agenda. In many cases, these interests are seen as incongruent with and independent of professions. As Johnson (1995) aptly put, this conception of the state-profession relationship is ...

... between preconstituted, coherent, calculating political subjects; one intervening, the other seeking autonomy. While the professions are seen as acting to maximize autonomy, the state is presented as continuously extending its apparatuses of control throughout society, including over the professions (p. 9).

This is particularly salient in the literature that addresses the decline of professional dominance, and of medical dominance in particular (e.g., Coburn et al., 1983; Wilsford, 1991). O’Neill (1998), for example, argues that contrary to much of the literature on professional dominance, the state is not a co-operative 
and acquiescent state actor. Coburn (1993) argues further that although historically state regulation of health occupations in Canada was mediated through medicine's control over the health care division of labor, more recently the state's involvement has become less medically oriented as the profession has come to be increasingly seen as the major barrier to a more "rational" (read: cost conscious) system of health care. Dent (2003) similarly argues that the neoliberal state with its focus on the markets and principles of new public management has undermined medical dominance. Indeed, a variant of the sociology of professions literature that draws upon institionalist theory unpacks the role played by states more recently in terms of "mediation" between institutional change and professional practice. Leicht et al., 2009, for example describe how liberal democratic states to respond to various economic crises through strategies like new public management, and this in turn shifts how professional groups see this type of strategy as a challenge to their "state recognized" expert role.

But when the state acts it may not necessarily be incongruent with the interests of particular professions as these analyses suggest. Larson (1977) describes how there can be a symbiotic relationship between professions and the state at certain times, observing that "organizational professions are generated ... by the expansion of the bureaucratic apparatus of the state" (p. 179). Johnson (1995) also details how the formation of the professions and the state in Britain were historically interrelated processes; the state became more powerful with the development of the professions and in turn the professions attained power through newly developed state apparatus:

[T] he state, as the particular form that government has taken in the modern world, includes expertise, or the professions. The duality, profession/state, is eliminated ... [b] ecause expertise is in this sense inseparable from those processes we call the state ... The expert is not sheltered by an environing state, but shares in the autonomy of the state (Johnson, 1995, p. 13).

Extending his analysis further and building upon Foucault's notion of governmentality, Johnson (1995) argues that the state is in part constitutive of the professions and their interests congruent. Both are elite segments of society and part of the institutionalization of expertise and the government of citizens.

To contrast with Johnson's argument, Krause (1996) criticized this view of concurrently developing state and professions arguing instead that professions developed well before the formation of the state as we know it. Perhaps the argument should not be that the professions and the state developed congruently but rather they attained legitimacy simultaneously. Moreover, as Doray et al. (2004) describe, the state has not only provided the regulatory frameworks that legitimizes professional projects but has also created markets for their services. Specifically referring to the context of European welfare states, Kuhlmann (2006) describes the state-professions relationship in terms of a social contract whereby the state had a vital interest in the expansion of markets for professional services while on the other hand it provided legitimacy for the state because it promised access to social services for the citizens. This enabled welfare states to translate the concept of social citizenship into the practice of social services. Similarly, Bonnin and Ruggunan (2016) detail how the strategies of the South African state affected the racialized composition of traditional professions, which in the post apartheid era led professional projects of the public service aimed at racial and gender transformation.

Thus, when we think about the state in terms of its agency what we find is a complex, interdependent, and historically varying relationship with the professions. One way to reconcile the two discrepant views on the state's interest $v i s-\grave{a}$ - $v i$ s the professions is to recognize that historically their interests aligned, but in a new neoliberal context they can be less congruent. The state forms, trains, institutionalizes, and employs professions and in turn, according to Johnson (1995), the professions lend expertise to the state together constituting tools of governing; similarly, as Bertilsson (1990) notes, professions act in the welfare state garnered interests of citizens. More recently, the interests of the state and some professions (particularly the more dominant or established professions) may be less congruent as state actors exercise more control over professional services in the public sector. As Larkin (2005) summarizes, "it can be asked whether the joint profession-state project has now run its course, or, as may be more likely, whether it is entering another and more pluralistic phase" (p. 29).

\section{Limitations of the Professions Literature}

Other than a few notable exceptions (e.g., Bertilsson, 1990, Coburn et al., 1999, Dent, 2003), the professions literature on the state's role in professional projects does not make linkages with the wealth of literature that more clearly outlines the role of the state in capitalist society and its internal structure and organization. The state tends to be viewed as a rather static monolith-whether it is as an audience or as an actor. Dent (2003) does unpack the different types of states within the European context-welfare state, neoliberal regime, and new paternalistic structures-highlighting how this affects the relations between the professions of medicine and nursing. This analysis still fails to recognize the relative importance of various segments of the state and the specific relations these segments have with particular professions or particular segments of professions. As a result, it is difficult to determine why some professionalizing strategies directed toward the state work while others do not.

In drawing upon these theories in my own work, I could not, for example, fully explain why the profession of midwifery in the Canadian province of Ontario achieved not only self-regulatory status but also inclusion into the publicly funded provincial health-care system, whereas in another province-Alberta-it did not. Prior to 1993, midwifery did not have a foothold in any Canadian provincial health system. After undertaking a comparative investigation (James and Bourgeault, 2004), we found that the political ideology of the governing party coupled with the structural context of the state policy making apparatuses varied significantly and had a differential impact on the similar professionalizing strategies undertaken by the two provincial groups of midwives. Because the policy literature proved to be so helpful in this comparative analysis, it was anticipated that pursuing a theoretical integration between these two literatures may help 
advance our understanding of the role of the state in professional projects more broadly.

\section{THE STATE IN THE POLICY LITERATURE}

In comparison to the professions literature, the policy literature is a rather vast enterprise. Those elements found to be most helpful in addressing country specific professional projects are the areas that discuss the role of interest groups in the policy-making process, the structure, and organization of policy communities and networks, and the broader literature on the role of the state in civil society. Comparative examinations of profession-state relations have relied on literature outlining state typologies (e.g., Dent, 2003) usually drawing on Esping-Anderson (2013) as described briefly above.

\section{Interest Groups, Policy Networks and the Policy-Making Process}

There are a variety of models of the policy-making process but the one with seemingly the most currency is the Kingdon (1995) model. This model includes the following four stages: (1) the setting of the policy agenda; (2) the specification of alternatives from which a choice is to be made; (3) an authoritative choice among those specified choices; and (4) the implementation of the decision. Arguably the most critical stage of the policy-making process is agenda setting, where Kingdon describes three separate streams-problems, politics, and policies-which must come together at a "window of opportunity" for issues to be taken seriously by policy decision-makers. The problem stream addresses the question why certain problems come to occupy the attention of government officials whereas others do not. The politics stream involves visible and hidden participants both inside and outside of government. The policy stream selects from the previous two streams, depending on a variety of sometimes conflicting criteria, proposals that will become formal public policy.

Central to the agenda-setting process are organized interest groups who identify a problem, use mass media to draw attention to it at "focusing events," and propose a set of policy solutions to the problem they have identified. Different interest groups-some with competing aims-can form networks of influence or policy communities which can also include relevant segments of government and other groups in civil society (Kingdon, 1995). In the case of professions, conceptualized as interest groups, they can raise issues that aim for greater professional autonomy, authority, or power and they can join with (or alternatively they can oppose) consumer interest groups in their endeavors.

Although the use of the interest groups concept can be criticized for espousing a similar kind of pluralist "all things being equal" approach leveled against the "state as audience" literature, the concept can be extended to more fully incorporate dimensions of power by drawing upon a key distinction in the types of interest groups: insider and outsider groups. The former are groups that are accepted as respectable or legitimate by government policy-makers and that often play a consultative role in policy creation; the latter are not perceived as legitimate and find it difficult to infiltrate the policymaking process (Grant, 2008). Another player in the policy making process is the policy entrepreneur who works within interest groups or within government. They "invest their resources-time, energy, reputation, and sometimes money-in hope for a future return ... in the form of policies of which they approve" (Kingdon, 1995, pp. 122-123). This is similar to what has been described as agents of professional projects or professional elites (e.g., Larson, 1977; Larkin, 1983; Witz, 1992). Their involvement in early stages of the agenda-setting process often involves a battle over shaping the definition of the problem in the public's mind in a way that furthers their professionalization seeking efforts (Rochefort and Cobb, 1994).

Clearly there is compatibility between the policy/interest group and professions literatures. But although both literatures highlight the importance of similar entities-interests groups/ professions and policy networks/systems of professions-each provides more or less detail on the context and processes important to the relations between professions and the state. The policy literature makes explicit what is sometimes implicit in the professions literatures in terms of the professionalization process, and the professions literature has more fully conceptualized the relations of power within policy communities that include professions. A number of questions still remain, including, what distinguishes outsider and insider (professional) groups, how an outsider group could become an insider group and why?

\section{Interests/Role of State in Society}

A promising direction to begin to answer the questions posed above would be to delineate the interests of the state in liberal democratic societies, which include both ensuring an environment conducive for the accumulation of capital while at the same time maintaining its own legitimacy vis-à-vis its citizens or the electorate which the state is supposed to represent (Knutilla, 1992). Perhaps Marx (1955) in the Communist Manifesto states the first role most emphatically: "the executive of the modern state is but a committee for managing the common affairs of the whole bourgeoisie." Taking the different roles of the state into consideration enables us to draw upon the discussions of the ideological compatibility of professions with capital. For example, Larson (1977) argues that, "intellectuals are obviously of strategic importance for the ruling class, whose power cannot rest on coercion alone but needs to capture the moral and intellectual direction of society as a whole" (p. xiv). Willis (1989) similarly argues in the case of chiropractic that there was a "compatibility of chiropractic knowledge with dominant class interests" (p. 197) given that back injuries are a major source of productivity loss in capitalist society. The role of the state $v i s-\dot{a}$-vis health professions becomes more complex when it is the main payer or provider of professional services as is the case in health care. Le Bianic (2003) highlights the important of distinguishing "the state's position as employer of professionals and it position as producers of rules in the direction of the professions. These roles frequently interfere with each other, giving rise to conflicts within the state apparatus (for example between the administrations employing professionals and the legislative power)" (p. 2).

The legitimacy role of a liberal democratic state is consistent with Bertilsson's (Bertilsson, 1990) description of how the policies of the welfare state embody the collective action of the 
citizenry. Similarly, Willis (1989) describes that despite opposition, exclusion, and internal divisions, chiropractic flourished in Australia, mainly due to the support and lobbying efforts of chiropractic clientele. Indeed, both he and Coburn and Biggs (1986) argue that state sponsorship of professionalization efforts are often bolstered by exhibitions of public/consumer support, which if large enough can be interpreted as potential electoral support for state actors. The importance of consumer support, particularly as viewed by key state actors, was revealed to be particularly important in the case of midwifery integration in the Canadian province of Ontario (Bourgeault, 2006).

Knowing more about the interests in which the state is purportedly acting helps us to better account for the differences in efficacy of the lobbying efforts of interest groups and professions. We can draw upon the policy and state literature further, first, by looking inwards and asking, "which interests take priority for any particular political party?" and further, "how do the different ministries or departments within any government, state bureaucrats, and elected officials from various political parties interact in response to those interests?" We know that more right-of-center, or conservative political parties tend to give primacy to the goal of capital accumulation when in government, whereas more leftof-center or social democratic political parties emphasize their legitimacy role. Even ministries within the state place a different emphasis on these roles with treasury/finance favoring its link to capital and the "social" ministries, like health and welfare, its link to the citizenry.

Abbott (1988) mentioned a similar distinction between ministries in the French state between one that governed professional work and one that controlled professional education, which had profound implications for professional development of the legal profession. It is unfortunate that these important distinctions and their clear impact on professional projects were not fully integrated into his conceptualization of the state in his system of professions treatise. Indeed, even after mapping out the power of the French state to organize professions and structure their jurisdictions over several pages, he concludes that, "the government, rather than the public or the workplace, is the dominant audience for professional claims" (p. 163, emphasis added).

Another important distinction to consider is the state's efficacy in meeting its objectives, partially captured in the conceptualization of strong versus weak states (Migdal, 2001). The strength of the state in turn depends in large part on the state's autonomy and its capacity. State autonomy refers to the degree of independence from societal groups possessed by state actors when they formulate policy objectives. State capacity denotes the ability of the state to draw on sufficient institutional resources both to design policies that will realize its policy objectives and to implement these policies. This latter point is linked back to the earlier discussion of policy communities and networks of influence.

We can also more fully unpack the state by looking outwards reflecting on the various types of welfare state. These have been described as including: (1) strong, interventionist welfare states; (2) soft compensatory welfare states; (3) full employmentoriented, small welfare states; and (4) market-oriented welfare states (Esping-Anderson, 2013). Similar to what was outlined for the leanings of political parties, the organization and orientation of welfare states can structure its interests in critical ways. Such an insight lends even more credibility to comparative investigations to more fully understand the role of the state (c.f., Benoit et al., 2005). Historically, we have also witnessed a contraction of the state or an evolution of "welfare states" to "welfare societies" to neoliberal/neoconservative "economizing" paradigms and a parallel shift in focus from the citizenry to the economy (Coburn, 2001). As MacDonald (1995) argues, "Certainly the terms 'welfare state' and 'corporatist state' have been used to characterize the third and fourth quarters of the twentieth century and these variants, it could be argued, have involved real and significant changes in the state/profession relationship" (p. 114). This has been particularly notable in the post 2008 financial crisis era that brought with it marked austerity budgets significantly impacting public sector health professions (c.f., Cervero-Liceras et al., 2015). These differences highlight the importance of not only attending to how the professions have changed historically but also how the state has changed as well.

\section{Limitations of the Policy Literature}

Although the policy literature enables an expanded conceptualization of the state-opening up the "black box"-it also suffers from limitations, some of which can be attenuated with reference to the professions literature. First, the policy literature often does not explicitly recognize the uniqueness of certain professions as interest groups. This is particularly true of the pluralist interest group view; while the elitist view recognizes varying degrees of interest group power, it does not fully examine the sources of this differential power. This is what some of the socially and historically situated professions literature can contribute to a more thorough integrated conceptualization.

Another contribution that the professions literature can make to some of the limitations that arise from the policy literature is regarding the recognition of problems in need of policy solutions. If we consider Johnson's (Johnson, 1995) expansion of the concept of governmentality, we might be better able to distinguish which problems can give rise to a policy response-those of central importance to governance. For example, the social problem linked most clearly to midwives professionalizing efforts in Canada was regarding the (then) unregulated practice of home birth-considered within mainstream medicine as an unsafe practice despite evidence of the contrary. Indeed, the most successful "focusing events" for the midwifery professional project were those that centered around the regulation or governance of midwifery attendance at planned home births. The practice of home birth and the attention media drew to the practice made it clear to government policy-makers at the time that this was a problem in need of a policy solution. Advisory committees called for the regulation of the practice of home births through the regulation of midwifery. Midwifery policy entrepreneurs anticipated that regulation would at the very least mean recognition so used these events to successfully propel their professionalizing efforts forward (Bourgeault, 2006).

While a conceptual integration of these two literatures proves helpful in explaining the creation of a social problem that led to policy recognizing midwifery, several questions still remain. Perhaps the most obvious is why the state is so interested in the 
control of birth or reproduction, as it has been throughout history. This issue and others relating to women's work and relationship with the state have been the focus of the recent growth in feminist literature on women and the state. This literature can further help to contextualize the gendered dimensions of the relationship between professions and the state.

\section{FEMINIST LITERATURE ON WOMEN AND THE STATE}

From the first wave of feminism (1870-1930) with its focus on women's political and property rights, to second wave of feminism (from 1960) which concentrated on the control over women's sexuality, fertility, and experience of violence, to third wave feminism concerned with experiences beyond the white, upper, middle class educated feminist elite, the state has been a focus of feminist analysis. Indeed, women's issues have moved from being a radical demand of feminists to a legitimate policy issue for various levels of government (Heitlinger, 1993). Similar to the legalistic tactics Witz (1992) described of female professional projects in Britain, other state-directed feminist initiatives have been relatively successful in advancing women's health and social justice issues. These include such issues as pay equity, access to abortion, and efforts to combat violence against women (Fox Piven, 1990, Newman and White, 2012), though they are constantly under threat, particularly under neoliberal and socially conservative austerity regimes (c.f., Armstrong, 2009, Bakker, 2009).

While feminist activists have recognized the emancipatory potential of the state, feminist analyses have also revealed the oppressive nature of the state. Many of the initial forays of feminist state scholars follow the Marxist, or representation school of thought, which argue that the capitalist state acts primarily in the interest of capital (Charles, 2000). Marxist feminists, such as McIntosh (1978), argue similarly that the state, at least historically, supports gender relations which are oppressive to women. This came to be known as "state patriarchy" (Eisenstein, 1984) and early radical feminists argued that on the whole, the state should either be avoided (Waylen, 1998) or acted against (Randall, 1998). More recent analyses describe how neoliberal state policies have had a disproportionately negative effect on education and health professions dominated by women (Beach, 2010).

The recognition that engagement with a liberal democratic state can have positive outcomes for women has resulted in a modification of this more one-sided view of the state by some feminists (Charles, 2000). That is, rather than reject the state, feminists have been encouraged to rethink their conceptions of it (Randall, 1998). This shift in perspective of Marxist feminists has mirrored the acknowledgment of Marxist scholars of the state that it is not monolithic; the state sometimes responds to political pressure from the working class. For example, Marxists have argued that universal provision of welfare by the state also legitimates its power by giving "the impression that the state 'cares' about its citizens and give them a reason to support the existing system" (Charles, 2000, p. 8). Similarly, Connell (1995) links the recent successes of feminist initiatives to the need of the state to maintain its legitimacy. She argues that a liberal democratic state is "obliged to respond to demands which are phrased in the discourse of liberalism," for if it does not, "such demands have the potential to call into question its legitimacy" (Charles, 2000, p. 26). Thus, as noted earlier, the state must not only respond to the interests of capital it must also maintain its legitimacy vis-à-vis its electorate, which includes women who increasingly constitute an electoral force, voting in favor of their own interests as women (Conway et al., 2004).

The impact of women on the state is not limited to its need to maintain legitimacy. One must also consider the internal workings of the state. In contrast to Marxist external representations of the state, Weberian theorists focus on the exercise of power and domination thereby fostering a renewed interest in the internal organization of the state, its contradictory elements instead of its appearance as a monolithic entity. That is, "viewed externally the state can be seen as a set of institutions which together constitute the state apparatus which has power over civil society ... viewed internally the state appears as a set of social relations which are in continual flux, it is seen as a process rather than a thing" (Charles, 2000, p. 13).

Feminist theorists argue that the internal organization of the state can be seen in terms of "institutionalized masculinity" (Connell, 1995, p. 24), which is that it is controlled by men and policies are biased toward the interests of men. This often means women are left to attempt to gain access to the state indirectly through outsider interest groups. It has been described that In the case of Canada, "women who took up the issue of women's equality were 'outsiders' in the male-dominated political system of representation, sidelined as lobbyists ... to influence the insiders"' (Bergqvist and Findlay, 1999, p. 126-127). As a consequence, women's organizations in Canada, and perhaps elsewhere, have tended to fall outside of the domain of established politics and remain isolated from standard sources of political power (Feldberg and Carlsson, 1999). Organizations that have more power vis-à$v i s$ the state, such as the medical profession when health policy is considered, tend to be under-represented by women in the upper echelons of its organizational hierarchy (Conway et al., 2004). In Heitlinger's (Heitlinger, 1993) comparative analysis of the success of women's initiatives as state "outsiders" in Canada, Australia, and the UK, she argues that such initiatives work best where there are flexible political structures that are open to a variety of interest groups, and where innovative liberal feminist groups are willing and able to engage in "pragmatic reformist politics" (p. 4). She argues further that "the ways in which feminist demands are formulated and translated into demands made on the state depends on the ideological predisposition of the women's movement and the political opportunities for feminist influence on government" (p. 20, emphasis added). This idea is similar to Larson's (1977) arguments regarding the ideological compatibility of professional projects with the logic of capitalism, and likely refers to an argument based on the ideology of liberalism (to resonate best with the legitimacy role of a liberal democratic state).

A more influential mode of interacting with the state could be described as the move from "outsider" to "insider" status (Conway et al., 2004). This mode of interaction may be accomplished by an increase in the number of elected female politicians, who may act 
as central agents within the state taking up the concerns of women. For example, it is as yet unclear what the remarkable action of the Canadian Prime Minister in 2015 to appoint a gender equal cabinet will have on the everyday lives of women and women's organizations. According to Arscott (1993), "the difference that [gender] difference in legislators can make includes the expansion of the range of issues considered to be political, the bringing of a gender-specific perspective to bear on already established issues, ... and a symbolic presence that helps in the continuing task of eliminating sex-based discrimination" (p. 16). This is particularly salient in those countries known for "state feminism," such as Sweden and other Nordic countries (Eduards, 1991). An alternate strategy that was adopted in Australia was to foster a group of femocrats (Eisenstein, 1996) whereby community-based feminist "outsiders" were integrated within state bureaucracies as representatives to help develop and implement policies to promote women's equality. These offer important strategies by which to challenge the existing legitimacy of male power within the state.

Creating a critical mass of women increasing the feminization of the state, or what Hernes (1987) coined, a "women-friendly" state, has arguably resulted in states being more responsive to women's issues, including those brought forth by femaleled professional projects. Indeed, it has led to the creation of "opportunity spaces" (Waylen, 1998) or "political opportunity structures" (Jenkins and Klandermans, 1995) whereby existing patterns of gender relations can be altered. These help to provide women or women's groups with opportunities to collaborate with influential state actors even if their intervention may be constrained and even shaped by such opportunities (Randall, 1998). That is, as Briskin (1999) argues, "state responsiveness is not without contradiction: issues raised by women are often taken over by the state and solutions reshaped and managed in ways that might not have been foreseen and are not always in women's best interests" (p. 12).

At the same time, if one teases apart the levels of the state, one uncovers a gendered order within it, where different branches of the state being more or less masculinized. Charles (2000), for example describes "the coercive sectors of the state are male dominated in comparison with those concerned with human service work such as health and education" (p. 25). Indeed, the evolution of the welfare state into traditional feminine domains of health, education, and child care may lead to the consequent increase in the proportion of women within the state both as elected representatives and as bureaucrats. Thus, it could be argued that the gender order of the family to a certain extent is reproduced in the various levels of the welfare state with the more powerful sectors such as finance still dominated by men. As a consequence, the strength of the resistance to the integration of women's interests remains embedded in the structures of representation and the practices of men who still dominate them (Bergqvist and Findlay, 1999). Similar arguments have been made of the stratification within the professions and indeed alliances can be formed between particular segment of professions and segment within the state apparatus. To effect substantial change, therefore, women either as insiders or as outsiders still need to have allies in the upper echelons of government.
Thus, there exists a paradoxical quality to the state when examined from a gendered perspective where it is "both enabling and constraining, ... oppressive and responsive to pressure for change" by women and women's groups (Charles, 2000, p. 28). That is, "although the state may be patriarchal and represent male power at a certain historical conjuncture, it is not essentially patriarchal and can therefore be changed" (Charles, 2000, p. 5). The change, however, may be more incremental than radical (Conway et al., 2004). Thus, the state is not static with respect to gender relations but evolving, dialectic, and dynamic; hence, it is important to examine the state at different junctures of time. We must also recognize the dialectical relationship between the structure of and agency within the state as it is impossible to understand actions without analyzing the structures that constrain those actions. Moreover, one needs to exercise caution not to assume that the interests of the state, capital, men and women are unitary within these various sites of struggle. An intersectionality lens that takes other critical identities including race, nationality, and citizenship status into consideration is essential.

\section{A HEURISTIC CONCEPTUAL MODEL OF PROFESSION-STATE RELATIONS}

\section{State Interests and Policy-Making Processes Meet Professional Projects}

Together the professions and policy literatures, both drawing upon an explicit gender perspective, can contribute to a heuristic conceptual model of the relations between the professions and the state depicted graphically in Figure 1. It depicts two intersecting systems - of the professions and of the state.

Within the "system of professions" component, the model identifies both the interprofessional relations between professions and the intraprofessional stratification of professions into its elite representatives and its membership or rank-and-file. It also delineates between professions that there are insiders to the policy-making process (i.e., a policy community) and those who remain outsiders. Outside status is meant to reflect both those groups that lack official state recognition and those that although recognized may nevertheless have limited access to the policymaking process that affects the context of their practice. Outside

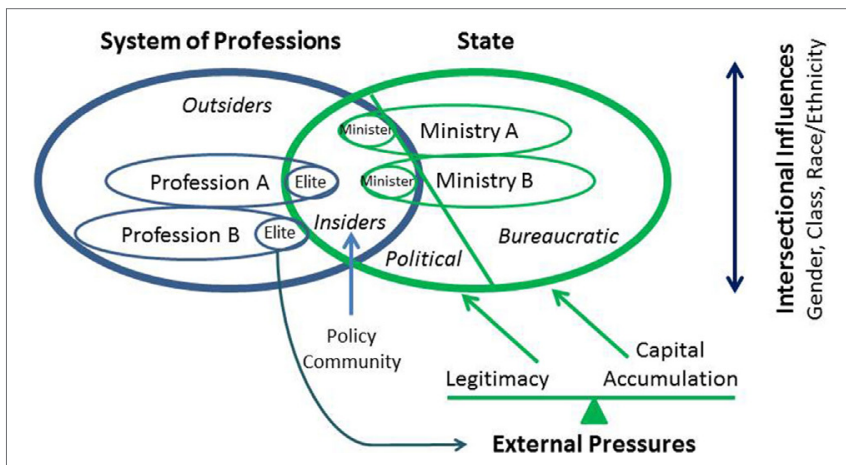

FIGURE 1 | A heuristic conceptual model of profession-state relations. 
professional groups can affect external pressure on the state, focused on either or both legitimacy and capital accumulation (and the related issue of cost-effectiveness of services if delivered through the public purse), depending on the political framing of their policy problem or professional project. Although this is represented as static, this should be seen as dynamic depending on the particular policy issue, profession, and political party in power.

Within the "state" components of this model, a distinction is made between the political and bureaucratic elements, highlighted in part by the identification of the Minister and his or her relationship with their respective Ministries. In addition to being responsive to external pressures placed on it by professional groups, it must be recognized that the state also has its own set of internal pressures to address. This is where strategic alliances can be most effective when efforts are taken up by internal state actors-whether from the political or bureaucratic arm. Other external pressures on the liberal democratic state include both legitimacy and capital accumulation. Depending on the economic context and political party in power, the balance of these pressures may tip in favor of one versus the other (noted by the scale).

As noted by the arrow on the right hand side, intersectional influences-in terms of gender, class, and racial/ethnicity orders-affect both the systems of professions and the state. Intersectionality is reflected in the intraprofessional hierarchies within professions, including who emerges as their elite or policy entrepreneurs, as well as in the interprofessional hierarchy in terms of which professions are considered insiders/ outsiders and have more access to political power. It is also reflected in an intersectionality within the state where different ministries, particularly finance, are privileged over others, including health.

What is not visually depicted in this heuristic model, but nonetheless important in the spirit of unpacking the state, is the relationship between various levels of governance depending on the country context, that is, between federal, provincial/state, and the municipal level within a country. This would add another layer of complexity to this two dimensional model, especially notable when finance and health ministries exists at different levels of government as is the case in Canada (Doray et al., 2004). The supranational relationships and trade agreements between states, such as the North American Free Trade Agreement and the European Union, should also be acknowledged as part of the broader context of influences on the relations between professions and the state in any one particular nation (Orzack, 1998, Le Bianic, 2003). These agreements exert additional external pressures, which arguably tip the balance in favor of capital accumulation. Nationally based professional groups are also increasingly drawing upon international research and professional networks in their professional projects. For example, the International Confederation of Midwives was influential in bolstering the lobbying efforts of midwives in various Canadian provinces for inclusion in the health-care system (Bourgeault, 2006). So there should be an additional local, regional, and international level of analysis of both the state and system of professions components of the model.
Also absent from the visual depiction of actors and organizations are the processes undertaken by these different actors in reaction to each other and different organizational influences in the model. Here is where the literature on the policymaking process, as exemplified by the Kingdon (1995) model, particularly complements more structural analyses. Kingdon's framework can help to shed light on three key elements: 1) the different actions undertaken and roles played by different actors within the professions (especially their elite or policy entrepreneurs); 2) how these are framed in terms of the problem, policy and politics stream, and 3) the strategic alliances developed throughout the various stages of the policy process can all affect the efficacy of different professional projects within the system of professions.

Although the model has primarily been discussed with reference to is gender dimensions, and gendered professional projects in particular, it is anticipated that it can also be applied in cases of other social cleavages such as class, age, ethnicity, or country of origin, through it may require some modifications pertaining to those literatures not addressed here. These social cleavages can influence both the "system of professions" components and the stratification within the state as has been identified by policy and professions scholars. In France, for example, the state was recently involved in the creation and to a certain extent professionalization of "social mediators," an occupational group that tended to be comprised of young men of North African descent paid to help fight social exclusion among their peers (Gadea and Divay, 2004). This model could be applied and modified to help explain why such a professional project was proposed in the first place (i.e., in response to the social problems of youth delinquency) and the reasons for its demise when the government discontinued the program in 2002. Similarly, the model could be used to address the growing political interest and analysis of the dynamics affecting the integration or social exclusion of internationally educated health workers into country-based health systems (Bourgeault et al., 2016). Moreover, this model could be similarly applied beyond professional projects to address deprofessionalization processes and professions reactions to these forces (Andrews and Waerness, 2011); its heuristic value is in its ability to help explain the changing dynamics of any change within the system of professions.

This heuristic model is intended to encourage scholarly investigations of professional projects to unpack the state to the same degree that the system of professions has been unpacked. It encourages the looking outward to the broader influences on the state's interest in the development of policy pertaining to professional projects as scholars of the professions have asked us to consider when examining the professions themselves. The model is also intended to better enable comparative analysis-both historically, between cases within a country, and between cases across countries-so as to more fully understand the variety of ways that different professions can interact with differently oriented and contextualized states. Finally, this model is heuristic in that it is in application to new cases that it is anticipated it will undergo modifications to better capture the dynamic relations between 
professions and states. The hope is that this model will invigorate more contemporary and critical analyses of the professions in changing social, political, and economic circumstances. It echoes the call from those within the field, as exemplified by Suskind and Suskind (2016), for the recognition of and more in-depth analysis of the changing role of professionals in the contexts of the increasing complexity resulting from massive

\section{REFERENCES}

Abbott, A. (1988). The System of Professions. Chicago: University of Chicago Press. Andrews, T., and Waerness, K. (2011). Deprofessionalization of a female occupation: challenges for the sociology of professions. Curr. Sociol. 59, 42-58. doi:10.1177/0011392110385969

Armstrong, P. (2009). "Social cohesion and the neoliberal welfare state: the health care example," in Women and Public Policy in Canada: Neo-liberalism and After? ed. A. Dobrowolsky (Canada: Oxford University Press), 87-106.

Arscott, J. (1993). "Between the rock and a hard place: women candidates for the legislature in Newfoundland and Nova Scotia," in Annual Meeting of the Canadian Political Science Association Meeting to be Held at Carleton University, Ottawa, ON.

Bakker, I. (2009). "Show us the money: tracking gender equality commitments and the "constraints" of Canadian budgeting," in Women and Public Policy in Canada: Neo-liberalism and After? ed. A. Dobrowolsky (Canada: Oxford University Press), 226-243.

Beach, D. (2010). Neoliberal restructuring in education and health professions in Europe: questions of global class and gender. Curr. Sociol. 58, 551-570. doi: $10.1177 / 0011392110367998$

Benoit, C., Wrede, S., Bourgeault, I., Sandall, J., De Vries, R., and van Teijlingen, E. (2005). Understanding the social organisation of maternity care systems. Midwifery as a touchstone. Sociol. Health Ill. 27, 722-737. doi:10.1111/j.1467-9566.2005.00471.x

Bergqvist, C., and Findlay, S. (1999). "Representing women's interests in the policy process: women's organizing and state initiatives in Sweden and Canada, 1960s-1990s," in Women's Organizing and Public Policy in Canada and Sweden, eds L. Briskin and M. Eliasson (Montreal: McGill-Queen's University Press), 119-146.

Bertilsson, M. (1990). "The welfare state, the professions and citizens," in The Formation of Professions: Knowledge, State and Strategy, eds R. Torstendahl and M. Burrage (London: SAGE), 114-133.

Bonnin, D., and Ruggunan, S. (2016). "Professions and professionalism in emerging economies: the case of South Africa," in The Routledge Handbook on Professions and Professionalism, eds M. Dent, I. L. Bourgeault, E. Kuhlmann, and J. L. Denis (London, UK: Routledge), 251-264.

Bourgeault, I. L. (2006). Push! The Struggle to Integrate Midwifery in Ontario. Montreal: McGill-Queen's University Press.

Bourgeault, I. L., Benoit, C., Wrede, S., and Neiterman, E. (2016). "Migration of expert labour," in The Routledge Handbook on Professions and Professionalism, eds M. Dent, I. L. Bourgeault, E. Kuhlmann, and J. L. Denis (London, UK: Routledge), 295-312.

Briskin, L. (1999). "Mapping women's organizing in Sweden and Canada: some thematic considerations," in Women's Organizing and Public Policy in Canada and Sweden, eds B. Linda and E. Mona (Montreal: McGill-Queen's University Press), 3-47.

Cervero-Liceras, F., McKee, M., and Legido-Quigley, H. (2015). The effects of the financial crisis and austerity measures on the Spanish health care system: a qualitative analysis of health professionals' perceptions in the region of Valencia. Health Policy 119, 100-106. doi:10.1016/j.healthpol.2014.11.003

Charles, N. (2000). Feminism, the State and Social Policy. New York: St. Martin's Press.

Coburn, D. (1993). State authority, medical dominance, and trends in the regulation of the health professions. Soc. Sci. Med. 37, 129-138. doi:10.1016/0277-9536(93)90137-S

Coburn, D. (2001). "Health, health care, and neo liberalism," in Unhealthy Times: Political Economy Perspectives on Health and Care, eds P. Armstrong, H. Armstrong, and D. Coburn (Toronto: Oxford University Press), 45-65. technological and economic transformations taking place in the political economy.

\section{AUTHOR CONTRIBUTIONS}

IB contributed $100 \%$ to this paper.

Coburn, D., and Biggs, C. L. (1986). Limits to medical dominance: the case of chiropractic. Soc. Sci. Med. 22, 1035-1046. doi:10.1016/0277-9536(86)90204-2

Coburn, D., Torrance, G., and Kaufert, J. (1983). Medical dominance in Canada in historical perspective: the rise and fall of medicine? Int. J. Health Serv. 13, 407-432. doi:10.2190/D94Q-0F9Y-VYQH-PX2V

Coburn, D. C., Rappolt, S., Bourgeault, I. L., and Angus, J. (1999). Medicine, Nursing and the State. Toronto: Garamond Press.

Connell, R. W. (1995). Masculinities. Sydney: Allen and Unwin.

Conway, M., Ahern, D., and Gertrude, S. (2004). Women and Public Policy: A Revolution in Progress, 3rd Edn. Washington: CQ Press.

Dent, M. (2003). Remodelling Hospitals and Health Professions in Europe: Medicine, Nursing and the State. London: Palgrave Macmillan.

Doray, P., Collin, J., and Aubin-Horth, S. (2004). L'État et l'émergence des « groupes professionnels. Can. J. Sociol. 29, 83-110. doi:10.1353/cjs.2004.0006

Eduards, M. (1991). Toward a third way: women's politics and welfare policies in Sweden. Soc. Res. 58, 677-705.

Eisenstein, H. (1996). Inside Agitators: Australian Femocrats and the State. Philadelphia: Temple University Press.

Eisenstein, Z. (1984). "On the relative autonomy of the capitalist patriarchal state," in Feminism and Sexual Equality, ed. Z. Eisenstein (New York: Monthly Review Press).

Esping-Anderson, G. (2013). The Three Worlds of Welfare Capitalism. Indianapolis: John Wiley \& Sons.

Feldberg, G., and Carlsson, M. (1999). “Organized for health: women's activism in Canada and Sweden," in Women's Organizing and Public Policy in Canada and Sweden, eds B. Linda and E. Mona (Montreal: McGill-Queen's University Press), 347-374.

Fox Piven, F. (1990). "Ideology and the state: women, power, and the welfare state," in Women, the State and Welfare, ed. L. Gordon (Madison: The University of Wisconsin Press), 250-264.

Freidson, E. (2001). Professionalism, the Third Logic. On the Practice of Knowledge. Chicago: University of Chicago Press.

Gadea, C., and Divay, S. (2004). From citizenship and ethnicity to professional qualification: the case of social mediators. Presentation to ESA Interim Professions Workshop, Lincoln.

Grant, W. (2008). The changing patterns of group politics in Britain. Br. Polit. 3, 204-222. doi:10.1057/bp.2008.3

Heitlinger, A. (1993). "Women's equality, childbearing and the state: an overview," in Women's Equality, Demography, and Public Policies: A Comparative Perspective (New York: St. Martin's Press), 1-21.

Hernes, H. M. (1987). "Women and the welfare state: the transition from private to public dependence," in Women and the State: The Shifting Boundaries of Public and Private, ed. A. S. Sassoon (London: Hutchinson), 24-42.

James, S., and Bourgeault, I. L. (2004). "To fund or not to fund: the fate of accessibility in Alberta," in Reconceiving Midwifery, eds I. Bourgeault, C. Benoit, and R. Davis-Floyd (Kingston/Montreal: McGill Queen's University Press), 131-149.

Jenkins, J. C., and Klandermans, B. (1995). “The politics of social protest," in The Politics of Social Protest: Comparative Perspectives on States and Social Movements, eds J. J. Craig and K. Bert (Minneapolis, MN: University of Minnesota Press), 3-13.

Johnson, T. J. (1995). "Governmentality and the institutionalization of expertise," in Health Professions and the State in Europe, eds T. Johnson, G. Larkin, and M. Saks (London: Routledge), 7-24.

Kingdon, J. (1995). Agendas, Alternatives and Public Policies, 2nd Edn. New York: Harper Collins. 
Knutilla, M. (1992). State Theories: From Liberalism to the Challenge of Feminism. Halifax: Fernwood Books.

Krause, E. (1996). Death of the Guilds. Professions, States and the Advance of Capitalism, 1930 to the present. Yale: Yale University Press.

Kuhlmann, E. (2006). Modernising Health Care: Reinventing Professions, the State and the Public. Bristol: Policy Press.

Larkin, G. (1983). Occupational Monopoly and Modern Medicine. London: Tavistock.

Larkin, G. (2005). "State control and the health professions in the United Kingdom," in Health Professions and the State in Europe, eds T. Johnson, G. Larkin, and M. Saks (London: Routledge), 25-30.

Larson, M. S. (1977). The Rise of Professionalism: A Sociological Analysis. Berkeley: University of California Press.

Lavis, J. N., Røttingen, J. A., Bosch-Capblanch, X., Atun, R., El-Jardali, F., Gilson, L., et al. (2012). Guidance for evidence-informed policies about health systems: 2 . Linking guidance development to policy development. PLoS Med. 9:e1001186. doi:10.1371/journal.pmed.1001186

Le Bianic, T. (2003). Bringing the state back in the study of professions. Some peculiarities of the French model of professionalization. Paper Presented at 6th ESA Conference Sociology of Professions Research Network, University of Murcia, Spain.

Leicht, K. T., Walter, T., Sainsaulieu, I., and Davies, S. (2009). New public management and new professionalism across nations and contexts. Curr. Sociol. 57, 581-605. doi:10.1177/0011392109104355

MacDonald, K. (1995). The Sociology of the Professions. London: SAGE.

Marx, K. (1955). in The Communist Manifesto, ed. S. H. Beer (New York: Appleton-Century-Crofts).

McIntosh, M. (1978). "The state and the oppression of women," in Feminism and Materialism: Women and Modes of Production, eds A. Kuhn and A. M. Wolpe (London: Routledge), 254-289.

Migdal, J. S. (2001). State in Society: Studying How States and Societies Transform and Constitute One Another. Cambridge: Cambridge University Press.

Newman, J., and White, L. (2012). Women, Politics, and Public Policy: The Political Struggles of Canadian Women, Second Edition. Canada: Oxford University Press.

O'Neill, M. (1998). Entrenched interests and exogenous change: doctors, the state and policy change in Canada and the United Kingdom. Commonw. Comp. Policies 36, 1-19. doi:10.1080/14662049808447758
Orzack, L. H. (1998). "Professions and world trade diplomacy: national systems and international authority," in Professions, Identity, and Order in Comparative Perspective, eds V. Oligiati, L. H. Orzack, and M. Saks (Onati, Spain: Onati Institute for International Study of the Sociology of Law), 13-37 (Onati Papers 4/5).

Randall, V. (1998). “Gender and power: women engage the state," in Gender, Politics and the State, eds V. Randall and G. Waylen (New York: Routledge), 185-205.

Rochefort, D., and Cobb, R. (eds) (1994). The Politics of Problem Definition: Shaping the Policy Agenda. Lawrence, Kansas: University of Kansas Press.

Sandall, J., Bourgeault, I. L., Meijer, W. J., and Schüecking, B. A. (2001). "Deciding who cares: winners and losers in the late twentieth century," in Birth by Design. Pregnancy, Maternity Care, and Midwifery in North America and Europe, eds R. De Vries, C. Benoit, E. van Teijlingen, and S. Wrede (New York: Routledge), $139-165$.

Schmidt, V. (2009). Putting the political back into the political economy by bringing the state back in yet again. World Polit. 61, 516-546. doi:10.1017/ S0043887109000173

Suskind, R., and Suskind, D. (2016). The Future of the Professions: How Technology Will Transform the Work of Human Experts. Oxford: Oxford University Press.

Waylen, G. (1998). "Gender, feminism and the state," in Gender, Politics and the State, eds V. Randall and G. Waylen (New York: Routledge), 1-77.

Willis, E. (1989). Medical Dominance: The Division of Labour in the Australian Health Care System, 2nd Edn. Sydney: George Allen and Unwin.

Wilsford, D. (1991). Doctors and the State: The Politics of Health Care in France and the United States. London: Duke University Press.

Witz, A. (1992). Professions and Patriarchy. London: Routledge.

World Health Organization. (2006). World Health Report: Working Together for Health. Geneva: World Health Organization.

Conflict of Interest Statement: The author declares that the research was conducted in the absence of any commercial or financial relationships that could be construed as a potential conflict of interest.

Copyright (c) 2017 Bourgeault. This is an open-access article distributed under the terms of the Creative Commons Attribution License (CC BY). The use, distribution or reproduction in other forums is permitted, provided the original author(s) or licensor are credited and that the original publication in this journal is cited, in accordance with accepted academic practice. No use, distribution or reproduction is permitted which does not comply with these terms. 